\title{
THE POTENTIAL OF SORGHUM PLANTS IN LAMUNDE VILLAGE TINONDO DISTRICT EAST KOLAKA REGENCY
}

\author{
Grace Onela Kambuno ${ }^{1^{*}}$, Abdi ${ }^{1}$, Abdul Gafaruddin ${ }^{1)}$ \\ ${ }^{1}$ Department of Agribusiness, Faculty of Agriculture, Halu Oleo University Kendari 93232 \\ ${ }^{*}$ Corresponding author: graceonelakambuno09@gmail.com
}

To cite this article:

Kambuno, G., Abdi, A., \& Gafaruddin, A. (2021). The Potential of Sorghum Plants in Lamunde Village Tinondo District East Kolaka Regency. International Journal of Agricultural Social Economics and Rural Development (ljaserd), 1(2), 63 - 72. doi:http://dx.doi.org/10.37149/ijaserd.v1i2.20552

Received: October 06, 2021; Accepted: December 09, 2021; Published: December 11, 2021

\begin{abstract}
Sorghum is one of the most important food crops globally, which has become the fifth food crop after wheat, rice, corn, and barley. Sorghum has excellent potential to be developed in Indonesia because it has wide adaptability, especially on dry land, and produces high productivity. This study aims to determine the possibility of sorghum plants in Lamunde Village, Tinondo District, East Kolaka Regency. The population in this study were sorghum farmers, totaling 25 people, using the method census or saturated sampling, which took the entire population as a sample so that 25 people were obtained as research samples. Data analysis used SWOT analysis using IFE (Internal Factors Evaluation) Matrix, EFE Matrix (External Factors Evaluation), and IE Matrix (Internal Externa). The results showed that the strategy that needs to be applied for sorghum farmers in seeing the potential for the development of sorghum plants in Lamunde Village is a strategy of concentration through vertical integration. Growth through engagement can be achieved through vertical integration by taking over the function of suppliers, namely sorghum farmers, or by taking over the tasks of distributors, namely buyers of sorghum production, either in the form of wholesalers or collectors and companies.
\end{abstract}

Keywords: potential; sorghum crops; SWOT analysis

\section{INTRODUCTION}

As an agricultural country, Indonesia has diverse biodiversity of food sources. One of them is sorghum. Sorghum (Sorghum Bicolor L.) is a cereal plant with great potential to be developed in Indonesia because it has a wide adaptation area. Sorghum plants are tolerant of drought and waterlogging, can produce on margin land, and are relatively resistant to pests/diseases. Sorghum seeds can be used as raw materials for the feed and food industry and the sugar industry, monosodium glutamate (MSG), amino acids, and the beverage industry. (Sirappa, 2003). Sorghum is a cereal crop that has been cultivated by Indonesian farmers for a long time, although with a relatively narrow area. Traditionally, sorghum is grown in Wonogiri and other regions in Central Java Province. The results of the sorghum crop can be used for food, raw materials, industrial products, animal feed ingredients, and energy sources (Irawan \& Sutrisna, 2011). Sorghum (Sorghum bicolor, Andropogon sorghum, Holcus sorghum, and Sorghum Vulgare) belongs to the grass family rice, corn, wheat, and sugarcane. Sorghum streams are similar to sugarcane, but smaller in diameter with a diameter of 2 $\mathrm{cm}$ high of old varieties of plants, can reach $2.5 \mathrm{~m}$. but the new is superior, and cane leaves. Malai grows at the ends of plants, just like rice. Sorghum seeds are also found in hard seed skins (chaff) than rice husks. Sorghum can be cultivated in tropical climates, savannas, deserts, to subtropical regions (Hermawan, 2018).

Southeast Sulawesi is one of the provinces with extensive agricultural land and is also one of the areas with dry land and can be used for developers of various types of food crops. This is an opportunity to cultivate sorghum because the sorghum development will not cause land-use competition with other commodities. The East Kolaka Regency Government develops sorghum covering an area of 1,200 hectares. This development supports and encourages farmers to build sorghum crops so that East Kolaka becomes a sorghum barn. Sorghum crops can be used as food, animal feed, industrial raw materials so that they will be able to be the forerunner of regional 
economic drivers (Ministry, 2020). The potential of the sorghum plant in Lamunde Village, in terms of price, is very high compared to other commodities. The cost of sorghum in Lamunde Village is IDR. 20,000, - to IDR. 25,000, -/kg compared to rice prices ranging from IDR. 9,000, -/liter. In Sorghum crop production, I produced 3.5 tons/ha in 2017, harvet II had 5.7 tons/ha, and the harvest was 2.6 tons/ha.

The Covid-19 pandemic became a difficult time for all communities, including farmers, because of the enactment of Restrictions on Community Activities (PPKM) to be one of the obstacles in developing sorghum. This significantly impacted the marketing of sorghum, where some farmers only market sorghum products in the regional scope, and it is difficult to market outside the region. This study aims to determine the possibility of sorghum plants in Lamunde Village, Tinondo District, East Kolaka Regency

\section{MATERIAL AND METHOD}

This research was carried out in July 2021 to completion in Lamunde Village, Tinondo District, East Kolaka Regency. Research sites were selected deliberately because the area has good sorghum potential. The population referred to in this study are farmers who have sorghum cultivation land as many as 25 farmers. Sampling is done by sampling saturated or other terms census, which can take the entire population as a research sample. One of the considerations of writing based on the experience of conducting research, in sampling using a census can be done if the population is less than 50 people. Thus the sample in this study amounted to 25 people. The data in this study were collected through surveys, interviews, and questionnaires. Then the data were analyzed using SWOT analysis using the IFE Matrix (Internal Factors Evaluation), the EFE Matrix (External Factors Evaluation), and the IE Matrix (Internal External).

\section{RESULTS AND DISCUSSION}

\section{Characteristics of Respondents}

Age

According to Soeharjo A and Patong (1984), age-based labor in agriculture is 15-54 years categorized as productive age, while ages $0-14$ years and 55 and above are classified as nonproductive age. productive (Soeharjo \& Patong, 1984). To find out the condition of the age of sorghum farmers in Lamunde Village, it can be seen in Table 1

Table 1. Age condition of sorghum farmers in Lamunde Village, Tinondo District, East Kolaka Regency, 2021

\begin{tabular}{cccc}
\hline No. & Age (Years) & Total (People) & Percentage (\%) \\
\hline 1. & $18-54$ & 21 & 84 \\
2. & $55>$ & 4 & 16 \\
\hline & Quantity & 25 & 100 \\
\hline
\end{tabular}

Source: Primary data after processing, 2021

Table 1 shows that the age of sorghum farmers in Lamunde Village aged 18-54 years is the highest, with a percentage value $(84 \%)$ being the age of sorghum farmers who are productive at work. The age of 55 years and over is the lowest, with a percentage value (16\%) being the age of non-productive. So it can be concluded that the average age of 18-54 years old sorghum farmers tend to be of productive age who have strong physical abilities and can think and have a high interest in sorghum farming activities.

\section{Level of Education}

The quality of human resources can be seen from the expertise/skills and knowledge they possess can also be described from the level of education they have completed. A person who completes his education to a high level of education can have broad knowledge and high skills/skills. The story of an education that a person has completed is marked with a certificate/diploma. With increasing skills/expertise, it will be easier to get opportunities to work (BPS, 2018).

Table 2 shows that a small number of sorghum farmers in Lamunde Village have not received a formal education, and most have taken formal education, namely SD, SMP, SMA. At the level of education, it is pretty influential in the implementation of farming activities, especially in knowing Science and Technology (IPTEK), including in making decisions related to farming 
Table 2. State of the education level of Sorghum Farmers in Lamunde Village, Tinondo District, East Kolaka Regency, 2021

\begin{tabular}{cccc}
\hline No. & \multicolumn{1}{c}{ Education Level } & Total (People) & Percentage (\%) \\
\hline 1. & No School & 3 & 12 \\
2. & Graduated from Elementary School/Equivalent & 11 & 44 \\
3. & Graduated from Junior High School/Equivalent & 8 & 32 \\
4. & Graduated High School/Equivalent & 3 & 12 \\
\hline \multicolumn{2}{c}{ Quantity } & 25 & 100 \\
\hline
\end{tabular}

Source: Primary data after processing, 2021

\section{Number of Family Dependents}

The number of family dependents is the number of children and family members whose entire living expenses are the respondent's responsibility, measured by the number of people. The more the number of dependents of the debtor's family, the higher expenditure. The number of family members determines the number of family needs. The more family members, the relatively large number of family needs that must be met so that they tend to be more motivated to work to meet their family's economic needs (Awal, 2018).

Table 3. Dependents of sorghum farming families in Lamunde Village, Tinondo District, East Kolaka Regency, 2021

\begin{tabular}{cccc}
\hline No. & Total of Dependents Family & Total (People) & Percentage $(\%)$ \\
\hline 1. & $1-4$ & 21 & 84 \\
2. & $>5$ & 4 & 16 \\
\hline & Quantity & 25 & 100 \\
\hline
\end{tabular}

Source: Primary data after processing, 2021

Table 3 shows the number of dependents of sorghum farming families in Lamunde Village, classified as minor family dependents, namely family dependents 1-4 people with a percentage of $84 \%$, and significant family dependents, namely $>5$ people with a rate of $16 \%$. This shows that the number of dependents in Lamunde Village is still classified as minor family dependents so that they can still meet family needs.

\section{Farming experience}

Farming experience is a learning process obtained by farmers for their farming work, thus simplifying the technology in developing farming. Farmers who have been farming for a long time will gain a lot of experience and are more skilled in working to process existing resources and increase farmer productivity.

Table 4. Experience of sorghum farmer farming in Lamunde Village, Tinondo District, East Kolaka Regency, 2021

\begin{tabular}{cccc}
\hline No. & Farming Experience (years) & Total (People) & Percentage (\%) \\
\hline 1. & 2 & 24 & 96 \\
2. & 4 & 1 & 4 \\
\hline & Quantity & 25 & 100 \\
\hline
\end{tabular}

Source: Primary data after processing, 2021

Table 4 shows the experience of farming sorghum farmers in Lamunde Village, namely farmers who have experience for four years totaling one person is the head of the Gapoktan who invites the community to the potential of sorghum plants. Although the average sorghum farmer only has two years of farming experience, they can turn Lamunde Village into a breeding village (supplier of sorghum seeds) and help the neighboring village of Talata as a sorghum plant development village.

\section{Internal Factors}

Internal Factors, namely strengths and weaknesses, based on direct field observations by the method used, strengths and weaknesses of the potential of sorghum plants during the Covid-19 pandemic in Lamunde Village, namely as follows. 


\section{Strengths}

\section{Experience of Farmers in Cultivating Sorghum}

Experience cannot be separated from everyday human life because it becomes a guide and learning for humans. Farmers also have beneficial experience and supportability to adopt technology in farming. An assumption is that the higher the level of knowledge gained, the farmer's mindset will also be more comprehensive. The results showed that sorghum farmers in Lamunde Village cultivated sorghum for \pm 2 to 4 years (Gustiana \& Irwanto, 2017). Although the experience of sorghum farmers is still low or still new, sorghum farmers have been able to turn Lamunde village into a sorghum seed breeding village for the development of sorghum plants. This is inversely proportional to the opinion of Aghis, et., al (2020) that farming experience is classified into three categories: (1). New experience ( $<10$ years), (2). Moderate experience (10-20 years), and (3). Long experience ( $>20$ years) (Aghis, 2020)

\section{Strategic Lands}

East Kolaka Regency has soil types from schist rock parent material $(\mathrm{pH}$ 5.15-5.79),

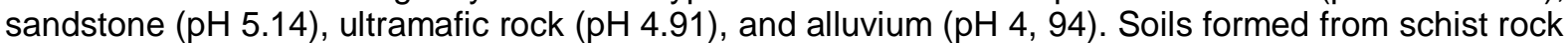
and ultramafic rock are well-drained, soils are formed from moderately drained sandstone, while soils formed from alluvium parent material are poorly drained (Yatno, 2016). The conditions for growing sorghum plants suitable for optimal growth are with a land height of $800 \mathrm{~m}$ above sea level, $\mathrm{pH} 5.0$ 7.5. Sorghum plants can adapt to a soil that is often waterlogged when it rains a lot when the root system is strong (Hermawan R. , 2018).

From the land classification in East Kolaka Regency, we know that the land in Lamunde Village is very strategic because it is by the requirements for growing sorghum plants. In addition, irrigation channels in Lamunde Village are perfect. The water supply for plants is sufficient, and there is still a lot of unused or untapped land so that the potential for developing sorghum is still significant. This is a strength for farmers in cultivating sorghum.

\section{Cooperation between farmer groups The}

Joint Farmer Group (Gapoktan) in Lamunde Village consists of 10 farmer groups where each farmer group consists of 25 members, and each farmer group has farmers who cultivate sorghum. It is guaranteed in the marketing of sorghum production because the farmers cooperate in collecting the show. Currently, the Gapoktan program for the development of sorghum in the neighboring village of Talata village with the first discourse of $100 \mathrm{Ha}$, Lamunde village currently as a sorghum breeding village will supply sorghum seeds for sorghum development in Talata village. The cooperation between the towns will help the development of sorghum cultivation in the future.

\section{Government Support}

The government's role in promoting economic growth is made in the National Long Term Development Plan (RPJPN) 2005-2025, stipulated through Law Number 17 of 2007. The elaboration of the RPJPN can create a competitive Indonesia to realize the basic needs of the community and the needs of the sector-related sectors through the role of government (RPIJM, 2006). The government in Lamunde Village advises farmers on the importance of cultivating sorghum because it is a multifunctional plant that can be used as food, feed, business raw materials, energy materials, and others. The role of the government in Lamunde Village can be in the form of assistance, such as milling, herbicide fertilizers, fungicides, and other infrastructure facilities.

\section{Weaknesses}

\section{Access to Lowcapital/money resources}

The weakness of each farmer usually leads to farming capital. Farmers in Lamunde Village are mostly their capital or private capital. The range of initial capital for sorghum cultivation is \pm IDR. $20,000,000,-/ \mathrm{Ha}$. Along with seeing the potential of sorghum plants, farmers are very enthusiastic about cultivating them because sorghum has excellent benefits. In sorghum cultivation, seed assistance from the Ministry already exists, but farmers still need capital to develop sorghum plants further.

\section{Technology limitations}

Although sorghum cultivation is generally categorized as easy to cultivate because sorghum is more accessible to grow than other crops, proper cultivation tools and technology are needed to 
develop sorghum. According to Hermawan (2018), in the development of sorghum technology is required, starting from the technology of seed preparation, superior seeds are obtained that have four unique characteristics, namely: a. germination (DB) Minimum 80\%, b. water content (KA) maximum $12-14 \%$, c. seed purity (KB) of at least $98 \%$, d. not contaminated with pests/diseases, not deformed, not wrinkled, pointed, shiny, and not mixed with dirt (dirt $<1 \%$ ).

Drying sorghum by mechanical means is drying with the help of a mechanically operated dryer. Some mechanical dryers are: (a) dryers with energy heat sources with fuel oil (diesel, kerosene, premium); (b) a dryer with a heat source of agricultural waste fuel energy; (c) a dryer with a solar energy heat source (Ratule \& Suarni, 2015)

\section{Lack of market information for farmers}

Sorghum is a new commodity in Southeast Sulawesi, so low market information. The standard market information is because internet network access in Lamunde Village has not been reached to all areas. Most farmers are also not accustomed to using mass media, so it is very influential on the marketing process of sorghum products. Sorghum farmers in Lamunde Village only rely on the head of the Gapoktan to market their sorghum products without knowing the marketing process for the sorghum products. From the results of this study, it can be seen that the lack of market information for farmers is one of the weaknesses in seeing the potential of sorghum because not all farmers get good market information.

\section{Low knowledge of farmers in cultivating sorghum}

The common knowledge of farmers about sorghum cultivation is one of the weaknesses of the potential of sorghum because most farmers do not know how to cultivate sorghum properly. Sorghum cultivation techniques can be carried out by (a) looking at the growing conditions for sorghum plants, (b) seed preparation and processing, (c) land preparation, (d) planting, (e) maintenance, (f) pest and disease control, and (g) post-harvest handling. Based on this, farmers need the training to know the correct technique in sorghum cultivation so that the role of agricultural extension workers is required in overcoming the potential weaknesses of sorghum plants (Hermawan R. , 2018)

\section{External Factors}

External Factors namely opportunities and threats, based on direct field observations by the method used, it can be seen what opportunities and threats from the potential of sorghum plants during the covid-19 pandemic in Lamunde Village, as follows.

\section{Opportunities}

1. High prices of sorghum

The price of sorghum is relatively high compared to other similar commodities, which is one of the opportunities for crop potential sorghum. The price range for sorghum is from IDR. 20,000, - to IDR. $25,000,-/ \mathrm{kg}$, and for grain sorghum, the price is IDR. 400 , - to IDR. 5,000, $-/ \mathrm{kg}$. Although the price of sorghum is relatively high, consumer demand is very high.

\section{Functional plants as food, feed, raw materials, and energy materials}

Sorghum is a functional plant because of the excess as food, feed, raw materials, and energy materials. In Lamunde Village itself, almost most of the sorghum farmers have made sorghum as a staple food other than rice, for animal feed, sorghum farmers have made sorghum stalks as animal feed, sorghum can be used as raw material in SMEs (Small and Medium Enterprises) one of which is made into flour, sorghum coffee, and other preparations. Sorghum as an energy source has been tried by one of the farmers in Lamunde Village. Initially, sorghum juice was made into ethanol for vehicle fuel.

\section{Availability of a market}

Availability of a market to sell sorghum products can be done directly by farmers to be sold to the community in Lamunde Village. For marketing outside the region, the chairman of Gapoktan has been able to market sorghum to Kendari, Makassar, Bulukumba, Pangkep, which are currently still within the scope of Sulawesi. The market demand for sorghum is increasing, and farmers make discourses on the development. 
4. Increase farmer's income

Income can be described as remuneration and cooperation of factors provided by farmers as movers, managers, and workers. The economic theory of income is all acquisitions are derived from the cost of production and the total output produced for all products in an economy within a certain period. Income, or profit,s the difference from revenue (return) where the amount of production is multiplied by the production price by the total costs incurred (Shinta, 2001). In Lamunde Village, each planting can produce up to 3 times, so that each harvest requires different prices.

Table 5. Costs and revenues obtained in Lamunde Village, Tinondo District, East Kolaka Regency

\begin{tabular}{cccccc} 
No. & Capital (IDR) & Price (IDR) & Harvest & Yield (Kg/Ha) & Income/year (IDR) \\
\hline 1. & & & I & 3.500 & \\
2. & $20.000 .000,-$ & $20.000,-$ & II & 5.700 & $216.000 .000,-$ \\
3. & & & III & 2.600 & \\
\hline \multicolumn{2}{c}{ Total } & & 11.800 & \\
\hline
\end{tabular}

Source: Primary Data Processed, 2021

\section{Public interest in sorghum}

The local community is very enthusiastic about the beginning of sorghum development in Lamunde Village because the benefits or properties are excellent. The community's enthusiasm is seen from the interest of several people who make sorghum a staple food, so the local government makes a sustainable program to cultivate sorghum. Lamunde village has become village captivity for sorghum under the supervision of a local agency, is currently being planned Gapoktan sorghum development in the town of Talata.

\section{Threats}

\section{Covid-19}

Law of the Republic of Indonesia Number 6 of 2018 concerning Health Quarantine is the restriction of activities and separation of a person exposed to an infectious disease as stipulated in the legislation even though he has not shown any symptoms to prevent the possibility of spreading to people around him (Law No. 6 years 2018). Government policies during the Covid-19 pandemic became a challenging time for farmers in Lamunde Village, and their farming activities were constrained inland processing, especially in marketing the results of sorghum farming. Currently, some sorghum farmers only sell their sorghum products within the region's scope because of the government's policy, namely PPKM, so it is difficult for farmers to market their products outside the area.

\section{Climate change}

A suitable climate for cultivating sorghum, the optimal temperature ranges from $23^{\circ} \mathrm{C}-30^{\circ} \mathrm{C}$ with a relative humidity of $20-40 \%$. In areas with an $800 \mathrm{~m}$ above sea level where the temperature is less than $20^{\circ} \mathrm{C}$, plant growth will be stunted. During plant growth, the required rainfall will be in the range of $375-425 \mathrm{~mm}$. Sorghum plants can adapt to soil that is often flooded when it rains when the root system is robust (Hermawan R. , 2018)

The problem currently being faced by sorghum farmers is high rainfall, occurring from June to August, which hampers sorghum growers in Lamunde Village. According to the (BMKG, 2021), rainfall data in the East Kolaka area reached the range of $235 \mathrm{~mm}$ in August 2021. From this, farmers are threatened in planting sorghum due to high rainfall, but the root system in sorghum is not yet strong, so farmers are not ready to plant. Farmers' plans for sorghum cultivation will continue if the rainy season is stable enough.

\section{Timing of planting at the same as other commodities (rice)}

In addition to rainfall, another factor that threatens farmers in cultivating sorghum is the timing of planting sorghum at the same time as other commodities (rice). Rice is one of the other commodities produced by sorghum farmers. This is what causes farmers to prefer to prioritize rice planting due to rainfall suitable for growing rice, so the farmers' initial plan to plant sorghum in August was constrained. 


\section{Analisis SWOT}

\section{Matrix IFE (Internal Factors Evaluation)}

According to Rangkuti (2005), the following stages or arrangements for formulating external strategic factors in the table are Strenght and Weaknesses as follows:

Table 6. Calculation of internal factors

\begin{tabular}{|c|c|c|c|}
\hline Internal Factors & Weight & Rating & $\begin{array}{l}\text { Weighting } \\
\text { Value }\end{array}$ \\
\hline \multicolumn{4}{|l|}{ A. Strenght } \\
\hline 1. Experience of farmers in cultivating sorghum & 0.20 & 4 & 0.8 \\
\hline 2. Strategic Land & 0.10 & 3 & 0.3 \\
\hline 3. Cooperation between farmer groups & 0.15 & 3 & 0.45 \\
\hline 4. Government support & 0.10 & 3 & 0.20 \\
\hline Strenght Score & 0.55 & 13 & 1.90 \\
\hline \multicolumn{4}{|l|}{ B. Weaknesses } \\
\hline 1. Access to Lowcapital/money resources. & 0.10 & 3 & 0.30 \\
\hline 2. Technology limitations & 0.15 & 3 & 0.45 \\
\hline 3. Lack of market information & 0.10 & 2 & 0.20 \\
\hline 4. Low farmer knowledge & 0.10 & 2 & 0.20 \\
\hline Weakness score & 0.45 & 10 & 1.15 \\
\hline Total & 1.00 & 23 & 3.05 \\
\hline
\end{tabular}

Source: Primary data after processing, 2021

The experience of farmers in cultivating sorghum is excellent, so this can be a significant factor in the power to see the potential of sorghum plants. As for the indicator of weakness, namely the limitations of technology, it needs to be addressed further because current technology is essential in developing a farm. The determination of this treatment is based on the considerations of the respondents regarding the potential of sorghum plants in Lamunde Village in measuring the performance of the indicators.

\section{Matrix EFE (Eksternal Factors Evaluation)}

According to Rangkuti (2005), the following stages or arrangements for formulating external strategic factors in the table are Opportunities and Threats as follows:

Table 7. Calculation of external factors

\begin{tabular}{|c|c|c|c|}
\hline External Factors & Weight & Rating & $\begin{array}{l}\text { Weighting } \\
\text { Value }\end{array}$ \\
\hline \multicolumn{4}{|l|}{ A. Opportunities } \\
\hline 1. High price of sorghum & 0.15 & 3 & 0.45 \\
\hline $\begin{array}{l}\text { 2. Functional plants as food, feed, raw materials, and energy } \\
\text { materials }\end{array}$ & 0.15 & 4 & 0.6 \\
\hline 3. Market availability & 0.10 & 2 & 0.2 \\
\hline 4. Increase farmer's income & 0.15 & 3 & 0.45 \\
\hline 5. Public interest in sorghum & 0.15 & 4 & 0.6 \\
\hline Opportunities Score & 0.70 & 15 & 2.3 \\
\hline \multicolumn{4}{|l|}{ B. Threats } \\
\hline 1. Covid-19 & 0.10 & 2 & 0.2 \\
\hline 2. Climate change & 0.10 & 3 & 0.2 \\
\hline 3. Timing of planting at the same time & 0.10 & 3 & 0.3 \\
\hline Thereat Score & 0.30 & 7 & 0.7 \\
\hline Total & 1.00 & 22 & 3.0 \\
\hline
\end{tabular}

Source: Primary data after processing, 2021

External factors on the chance that we can see the potential of the sorghum plant. On the threat factor in looking at the prospect of sorghum plants, it can be seen that there is a need for further anticipation and handling so as not to have an impact on the potential and development of sorghum plants. 


\section{IE Matrix (Internal External)}

Based on the analysis of internal and external factors, an illustration is obtained to determine the IE matrix for sorghum commodities made from the weighted values in the IFE and EFE matrices. The potential of sorghum plants during the COVID-19 pandemic in Lamunde Village has good enough potential to be developed further. This can be seen from the comparison between internal and external environmental conditions. The weighting value on the IFE matrix is 3.05 while the EFE matrix is 3.0, so that the IE matrix can be presented in Figure 1.

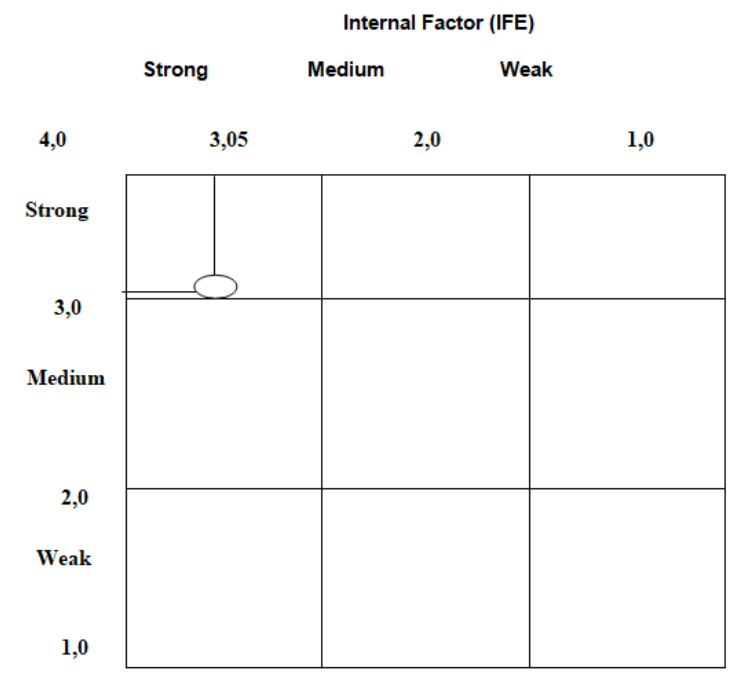

Figure 1. Internal External Matrix (IE) Sorghum

Based on Figure 1. located in cell (1), information is obtained that the strategic position of the internal and external environment of the potential of sorghum plants is a growth strategy that focuses on Concentration through Vertical Integration. According to Rangkuti (2005), growth through concentration can be achieved through vertical integration by taking over the function of a supplier or by taking over the role of a distributor. The supplier function is sorghum farmers, and the distributor function is the buyer of the sorghum production, either in the form of wholesalers or collectors, companies, etc.

\section{Matriks SWOT (Strenght Weakness Opportunities Threats)}

Table 8. SWOT Matrix

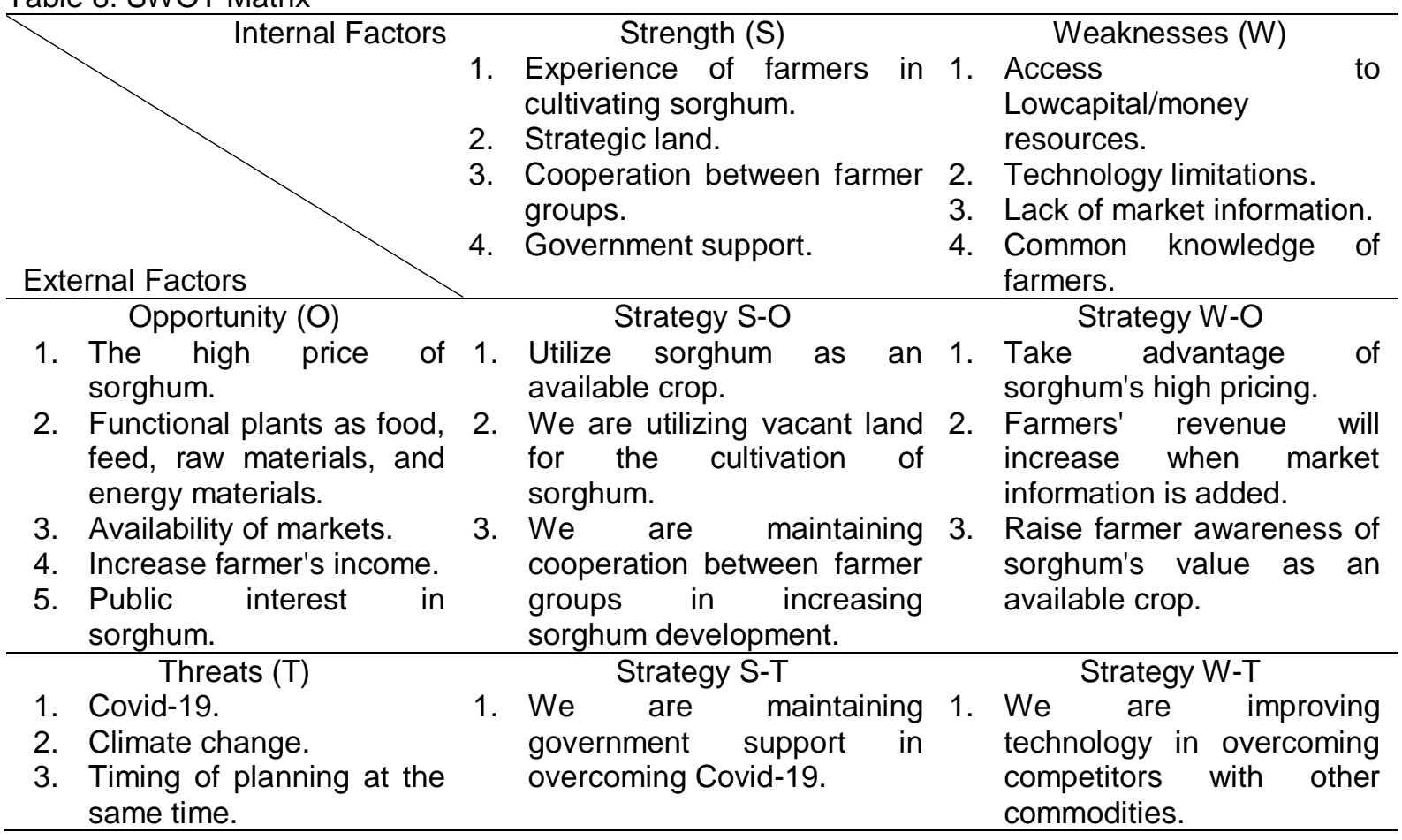


Based on Table 8 From the SWOT matrix, we can find out the potential strategy and development of sorghum in Lamunde Village, Tinondo District, East Kolaka Regency, as follows:

\section{Strategy S-O}

1. Utilize sorghum as an available crop.

Farmers must be able to take advantage of every potential of the sorghum plant, namely being able to use sorghum as a staple food, make sorghum as animal feed, plant sorghum as a raw material for farming and utilize sorghum as an energy source.

2. We are utilizing vacant land for the cultivation of sorghum.

Lamunde Village still has vacant land, so that farmers are expected to use unused land for sorghum cultivation. From this, the government's role and support are needed in assistance in land management.

3. We are maintaining cooperation between farmer groups in increasing sorghum development.

Seeing the excellent cooperation between farmer groups will be one of the potential strategies for sorghum plants in developing sorghum in Lamunde Village and other villages. The strategy that needs to be implemented is always to maintain good communication between farmer groups and help each other in farming activities and community activities so that a common goal can be achieved.

\section{Strategy W-O}

1. Take advantage of sorghum's high pricing.

Harga Sorgum di Desa Lamunde kisarannya mulai IDR.20.000,- sampai IDR.25.000,-/kg. dari hal tersebut kita dapat melihat harga sorgum yang relatif tinggi. Adapun strategi yang dapat diterapkan untuk memamfaatkan peluang tersebut dengan cara meningkatkan produksi dan mengolah sorgum menjadi produk-produk yang memiliki nilai jual yang lebih tinggi.

2. Farmer's revenue will increase when market information is added.

Sorghum prices in Lamunde Village range from IDR. 20,000, - to IDR. 25,000, -/kg. From this, we can see the relatively high price of sorghum. The strategies that can be applied to take advantage of these opportunities are increasing production and processing sorghum into products with a higher selling value.

3. Raise farmer awareness of sorghum's value as an available crop.

The role of extension workers is needed to assist sorghum farmers in increasing knowledge about sorghum cultivation techniques to proper post-harvest processing to get maximum results from sorghum plants so that farmers can utilize sorghum as an available crop (as food, animal feed, industrial raw materials, and energy material).

\section{Strategy S-T}

1. Maintaining government support in overcoming Covid-19

Every license and assistance from the government will help sorghum farmers see the potential of sorghum plants, even though during the Covid-19 pandemic, the government always directs the public to comply with health protocols to reduce the spread of Covid- 19 .

\section{Strategi W-T}

1. We are improving technology in overcoming competitors with other commodities.

Farmers can apply this strategy to overcome competition with other commodities because technology makes it easier for farmers to cultivate sorghum so that sorghum plants do not compete with other things.

\section{CONCLUSIONS AND SUGGESTIONS}

Based on the results of research on the potential of sorghum during the COVID-19 pandemic in Lamunde Village, Tinondo District, East Kolaka Regency, it can be concluded that the strategy that needs to be applied for sorghum farmers in seeing the potential to develop sorghum plants in 
Lamunde Village is a concentration strategy through vertical integration. Growth through concentration can be achieved through vertical integration by taking over the function of suppliers, namely sorghum farmers, and by taking over the tasks of distributors, namely buyers of sorghum production, either in the form of wholesalers or collectors, companies, etc.

\section{REFERENCE}

Aghis, et al. (2020). Capacity building of farmers in the application of biopesticides for pest control on paddy rice (Oryza sativa L.) in Ciasmara Village, Pamijahan District. Journal of Research Innovation (JIP), 1(4):647-657.

Awal, A. (2018). The Effect of Income and Number of Dependents of Rice Farmers on Children's Education Levels in Pattallassang Village, Pattallassang District, Gowa Regency. Faculty of Islamic Economics and Business, UIN Alauddin Makassar.

BMKG. (2021). Rainfall Analysis in August 2021 and Rain Forecast for October, November, and December 2021. Meteorology, Climatology and Geophysics Agency.

BPS Southeast Sulawesi. (2018). Indicators of People's Welfare of Southeast Sulawesi Province. BPS Southeast Sulawesi Province.

Gustiana \& Irwanto. (2017). The Effect of Production Coasts, Experience, and Skills on Cocoa (Theobroma cacao) Farming Income in Karang Baru District, Aceh Tamiang Regency. AGRISAMUDRA, Research Journal , 4(2):67-76.

Hermawan, R. (2018). The Business of Cultivating Sorghum The Master of Dry Land. Yogyakarta: Pustaka Baru Press.

Irawan \& Sutrisna. (2011). Prospect of Sorghum Development in West Java to Support Food. Agricultural Technology Research Center. 99-113.

Law of the Republic of Indonesia Number 6 of 2018 concerning Health Quarantine.

Rangkuti. (2005). SWOT Analysis Techniques for Dissecting Business Cases. Jakarta: PT. Gramedia Pustaka Utama.

Ratule \& Suarni. (2015). The Role of Postharvest Technology in the Development of Sorghum as a Food Diversification and Bio-Industry Material. Cereal Crops Research Institute.

RPIJM East Kolaka. (2006). Chapter 3 Policy Directions \& Strategic Infrastructure Plan for Human Settlements. RPIJM East Kolaka 2015-2019.

Shinta. (2001). Farming Science. Malang: Brawijaya Press University.

Sirappa. 2003. Prospects of Developing Sorghum in Indonesia as an alternative commodity for food, feed, and industry. South Sulawesi Agricultural Technology Study Center. 133-140

Soeharjo \& Patong. (1984). The Basic Joints of Farming Science. UNHAS.

Soniasi, W. (2020). Marketing Strategy for Seaweed in Kawite-Wite Village, Kabawo District, Muna Regency. Faculty of Agriculture, Halu Oleo University.

Yatno, E. (2016). Land Suitability Criteria for Cocoa Crops in Kolaka and East Kolaka Districts, Southeast Sulawesi. Easy. Graduate School, Bogor Agricultural University. 